University of Louisville

ThinkIR: The University of Louisville's Institutional Repository

Electronic Theses and Dissertations

1934

\title{
The role of membranes and phase boundaries in generating electric currents in living tissues.
}

Norman E. Epstein

University of Louisville

Follow this and additional works at: https://ir.library.louisville.edu/etd

Part of the Biochemistry, Biophysics, and Structural Biology Commons

\section{Recommended Citation}

Epstein, Norman E., "The role of membranes and phase boundaries in generating electric currents in living tissues." (1934). Electronic Theses and Dissertations. Paper 1774.

https://doi.org/10.18297/etd/1774

This Master's Thesis is brought to you for free and open access by ThinkIR: The University of Louisville's Institutional Repository. It has been accepted for inclusion in Electronic Theses and Dissertations by an authorized administrator of ThinkIR: The University of Louisville's Institutional Repository. This title appears here courtesy of the author, who has retained all other copyrights. For more information, please contact thinkir@louisville.edu. 
UNIVERSITY OF IOUISVIIIE

THE ROLE OF MEMBRANES AND PHASE BOUNDARIES IN

GENERATING ELECTRIC CURRENTS IN IIVING

TISSUES.

\author{
A Dissertation \\ Submitted to the Faculty \\ of the Graduate School of the University of Iouisville \\ In Partial Fulfillment of the \\ Requirements for the Degree \\ of Master of Sclence
}

Department of Physiology and Pharmacology

(Biophysics)

By

Norman E. Epstein

1934 


\section{CONTENTS}

I. THE PHASE BOUNDARY POTENTIAI THEORY - ITS APPLICATION TO:

A. Organic Acids...........................

1) Experimental Proof.................... 9

2) Shaking and Titration Experiments with Organic Aolds

B. Organic Bases.

1) The Inverse Blectromotive Effect of Organic Bases......................... 14

2) Shaking and Titration Experiments with Organic Bases....................... 16

II. EXPERIMENTAI EVIDENCES AGAINST MICHAEIIS' PORE THEORY.

A. Experimental Prote that Collodion is not an Inert Substance.............

B. Experiments with Dry Collodion Membranes in Which Iiquid is Insetted Between the KCI solution and the Collodion.

C. Experiments to Show that the Electric Potential of a Mixture of Two Electrolytes is not a Middle Value of the Value of the Two $\theta 0 m-$ ponents.

III. SUMRARY 


\section{ACKNOWLEDGEMENT}

For his stimulating guidance and generous assistance, I am deeply grateful to $\mathrm{Dr}$. Reinhard Beutner, who suggested the research and publication of this paper. His tremendous background at all times facilitated the progress of the investigation of my subject. I wish, too, to thank Dr. George E. Wakerlin for his counsel and sympathetic efforts in my behalf; also Mr. Gross and Mr. Goodman who proof-read this manuscript.

Norman E. Epstein. 


\section{GENERAI REMARKS}

"I can see no reason for the pessimistic assumption that the artificial transformation of dead into living substance might not be accomplished sometime." * It is this spectacular but not unreasonable hope which has stimulated a widespread interest among the scientific investigators and speculators in biophysical phenomena.

While many of the processes which occur in living substances cannot be reconstructed for demonstration, still artificial models may be devised which do imitate and correspond to the physicochemical reactions taking place in the living system. It is true that the composition of these models may differ from that of the living; however, much can be learned from their behavior, and can serve as a guide to the ultimate discovery of the true nature of life.

At the present time most of the attention of biophysicists is centered on the behavior of membranes in generating electric currents in living tissues. It is the hope of the author that this paper will contribute to the advancement towards the understanding of this subject.

* J. Ioeb, "Dymamics of Iiving Matter," Chicago, 1906. 


\section{HISTORICAI INTRODUCTION}

Eleotrophysiology, as a science, had its beginning in the year 1786 in Galvan1's famous discovery (1737-1798) which seemed largely to be accidental in nature. Galrani (2) was conducting some experiments on the museles in the legs of frogs and his attention was called to the violent and spasmodic contractions of the muscles when they were touched in certain way with a pair of prongs containing $\mathrm{Cu}$ and $\mathrm{Zn}$. From this observation, Galvani assumed that the twitching of the muscle was due to some form of electricity. However, he was in error in believing that some inherent vital force created this electricity.

Count Allesandro Volta (1745-1827), professor of physics at Parvia, was able to explain almost as accurately as we know today, the real cause of the muscular contraction observed in Galvani's experiment. Volta, showed experimentally, that on electric current could be produced by placing a piece of copper and a piece of zinc in a solution of sulfuric acid or some other electrolyte. From this experiment Volta was able to conclude that in Galvani's work, the frog's leg played the role of an intermediate salt solution and did not create currents of its own account. Volta, however, was not entirely correct in his theory. He believed that the junction of the 
two metals - $\mathrm{Cu}$ and $\mathrm{Zn}$ - In the cell arrangement was the only location where eleotricity was produced and also that living tissue never gives rise to electrioity.

Fifty years later, after Volta's femous alscovery, Du Bois Reymond (1818-1896), a frenchman, gave proof that organic tissues do produce electric currents. Du Bois Reymond ( 1 ), in attempting to explain the origin of these electric currents, adopted the theory of biploar molecules which merely states that the smallest particles of living tissue are positively charged at one end and negatively at the other. Da Bois Reymond, in adopting this theory was greatly influenced by Weber's theory of "Molecular Magnets" and he tried to correlate his biploar theory with that of Weber's which was the most alscussed theory at that time. Reymond's theory is important merely because it had postulated that some substance present in tissue, a priori was the cause of the current detected.

Iouis Hermann, a former pupil of Du Bois Reymond, condemned the conclusions of his former master. Hermann, in his "Alteration" theory, postulated that living tissue should be devoid of all electric potential differences and that potential differences should arise merely as a consequence of death, decay or degradation of life processes. To prove this basic 1dea that electricity was produced by degrading changes, Hermann showed that the infury current appeared within a definite 
time after the injury was inflicted. He found this period of time to be extremely short, being about $1 / 1000$ of a second, and thus he interpreted it to be the time required for the cut surface of a musele to pass from life to death. Hermann's theory, however, contridicts simple physical evIdence which shows that electrical potential differences exist at every boundary of differentiated living structures. His alteration theory could be true only if living tissue were homogeneous throughout.

In 1890 W. Ostwald, \& well known physical chemist, introduoed the hypothesis that membranes endowed with a differential permeability for positive and negative lons should be the peculiar cause of bloeleotricity. At the present time, I. Michaelis 18 an ardent supporter of this hypothesis. His reasons for supporting it as well as many arguments againgt it will be discussed later, in muah more detall.

Thus electrophysiologists have known for a long time that electric phenomena are associated with life and that they arise in living tissues. Howerer many of the investigators consider bioelectricity as so closely associated with life processes that reproduction of anything remotely resembling these phenomena by synthetic means is considered impossible. This is certainly not tme. It is quite possible to reproduce by artificial means many of the essential underlying conditions which are responsible for the generation of electric ourrents in 
tissues, and to observe how such artificial systems produce potential differences in a similar manner. As a matter of fact no explanation of bioelectricity can be adequate unless it is based on an imitation of the natural phenomena. The anclent bellef that all organio substances are produced by dint of the vital force has been gradually dying out since thousands of such substances are now being prepared synthetically.

Since it has been definitely proven that electric currents arise in living tissue, sensitive electrometers have been devised by means of which the electromotive force produced, when an electric current passes through a living tissue, has been accurately measured. Artificial models have been constructed containing systems similar to those found in living cells and their electromotive forces were measured. To the regret of the biophysicists, the electromotive forces produced in artificial systems were found to be ten times weaker than that of a living cell. In $1911 \mathrm{~J}$. Loeb suggested to R. Beutner (3) that he investigate the potential difference between such substances as apples or leaves of the rubber plant instead of the potential difference of muscles or nerves. In the subsequent experiments $R$. Beutner made the important observation that the potential difference between the surface of an apple or a leaf was a maximum where the bounding liquid was pure water while the potential difference was depressed when a salt was added 
to the water, the depressing effect on the potential difference increasing with the concentration of the salt.

A search was made for those substances in the cortex of an apple or leaf which might be responsible for these peculiar concentration effects on the potential difference. It was already known that the cuticula of the apple was a homogeneous wax-like covering consisting chemically of a mixture of fatty acids and higher alcohols and therefore lipoidal in character. R. Beutner, aiming at a further and more lucid explanation of the electromotive forces at plant outioula found that there existed a potential difference at the boundary of lipoids which was similarly depressed and likewise, the more so, the higher the concentration of the salt.

The idea that lipoids are the substances responsible for the potential difference of tissues led $R$. Beutner to an extensive study of the potential difference at the boundary of water immiscible substances and various salt solutions. Cell systems composed of aqueous salt solutions and non-aqueous water immiscible conductors were set up. The aqueous salt solutions of varying concentrations used were sodlum chloride, calcium chloride, potassium chloride, and sodium sulfate while phenol, salioylic aldehyde, cresol and guaiacol were used as central conductors. Results showed that the electromotive forces of these artificial cell systems were similar in strength 
to those of living tissues. From these results, R. Beutner (1) concluded that it is only by interposing electrolytio conductors that are water immiscible between the aqueous solutions in the electrolytic cells that electromotive forces can be produced in a similar order of magnitude to those which appear in living tissues. To comprehend these phenomena a careful understanding of the phase boundary potential theory, which is discussed in detall in the next part of this paper, should be sought. 
THE FHASE BOUNDARY POTENIIAI THEORY AND ITS APPIICATION. 
The Phase Boundary Potential Theory and its Application.

The phase boundary fotential theory is applicable to those systems mentioned abore (see p. 7 ) which are set up by a nonaqueous substance between two solutions of the same salt having different concentrations. In these systems, the ratio of the ionic concentrations in the two neighboring phases determines the potential difference. We should expect therefore that whenever an effect of concentration appears, the concentration of the common ion in the second phase should be independent of the aqueous salt concentration or at least nearly independent. If these two ionic concentrations underwent parallel variations, as one might expect according to the law of partition, no eleetromotive effect should manifest itself. Experimental evidence shows howerer, that these two lonic concentrations do not always undergo parallel varlation; hence the law of partition cannot be applied in its simplest form. This is clearly shown by the numerous experiments performed by $R$. Beutner (2).

\section{Experimental Proof}

Shaking experiments were performed according to the following procedure. In every series of experiments a constant volume of a particular water immiscible substance was shaken with an equal volume of salt solutions of different concentrations, all 
othei conditions remaining unohanged. The rise in conductivity was observed as a measure of lonic concentration which existed when the water immiscible substance was shaken with the aqueous salt solution. It appeared, very strikingly, in many cases that the conductirity of the central conductor was not greatiy inIluenced when it was shaken with two salt solutions of highly different concentrations.

Example:

A solution of a salt of an organio base was shaken with salicylic aldehyde for several hours.

(1) 12.5 c.c. of salicylic aldehyde +50 c.c. $1 / 125$ dimethylaniline $\mathrm{HCl}$

(2) 12.5 c.c. of salicylic aldehyde +50 c.c. $1 / 5$ M dimethylaniline HCl

After several hours of shaking the conductivity of salicylic aldehjde, in both cases, was measured.

(1) conductivity of salicylic aldehyde before shaking 0.7 rec. megohms

(2) conductivity of salicylio aldehyde after shaking with $1 / 125 \mathrm{~W}$ of dimethylaniline $\mathrm{HCl}$

7.8 rec. megohms

(3) conductivity of salicylic aldehyde

after shaking with $1 / 5 \mathrm{M}$ dimethyleniline $\mathrm{HCl}$

19.9 rec. megohms

Whereas the proportion of the concentrations of the aqueous salt solutions was 1:25; the ratio of the conductivities of the two salicylio aldehydes was $1: 2.5$. From these proportions it 
is apparent that the rise in conductirity of the salicylic aldehyde did not vary in the same ratio as the concentrations of the salt solutions and from this R. Beutner deduces that the law of partition does not function here in 1ts simplest form. If oresol plus oleic acid were used as a central conductor between various inorganic salt solutions we would also observe the effect of an electromotive force as soon as the concentration of the salts raried. According to the theory as stated above, the variability of the electromotive force of a system should depend on the constancy of the common ion in the water immiscible substance. If a system were set up where $\mathrm{NaCl}$ soiutions of varying concentrations were used with cresol plus oleic acid, then a difference in potential would be produced due to the constancy of the $\mathrm{Na}^{+}$ions in the oleic acid. This constancy is effected in the following manner. The $\mathrm{Na}$ ion penetrates into the oleic acid and combines with it to form sodium oleate, a soap, the formation of this soap depending only on the amount of oleic acid present which almost always remains constant. This phase boundary phenomenon between oleic acid and the NaCl solution leads us to the assumption that a chemical reaction occurs between the water immiscible substance and the adjacent salt solution.

$$
\mathrm{NaCl}+\mathrm{C}_{17} \mathrm{H}_{33} \mathrm{COOH} \longrightarrow \mathrm{C}_{17} \mathrm{H}_{33} \mathrm{COONa}+\mathrm{HCl}
$$

Such a chemical reaction seems contrary to a general chemical experience since HCl will decompose Na oleate to oleic 
acid and $\mathrm{NaCl}$. Nevertheless, the reaction proceeds in the manner indicated as can be demonstrated by titration experiments.

When a solution of oleic acid plus cresol is added to a sodium chloride solution and then the mixture is agitated, hydrochlorio acid is formed and is detected by titration. Control experiments are necessary since cresol plus oleic acid gives off traces of an acid even to pure water when shaken with it, but when shaken with sodium chloride more acid is formed as demonstrated by the following tests.

$$
\begin{aligned}
& 20 \text { c.c. of cresol plus } 1 \% \text { oleic acid } \\
& \text { are shaken with } \\
& 20 \text { c.c. of water or } 0.1 \text { W NaCl solution } \\
& \text { for four hours }
\end{aligned}
$$

After the shaking is completed the layers are separated by centrifuging and filtered. Equal quantities of the filtrates were then titrated, but before this was done as much sodium chloride was added to the water, which had been shaken with the cresol mixture, as was conteined in the original sodium chloridecresol mixture. In other words, the two solutions had the same $\mathrm{NaCl}$ content at the time they were titrated. Thus the possibility of a salt error in titration is excluded. The result was that the sodium chloride solution required five times as much more $0.01 \mathrm{M} \mathrm{NaOH}$ than the water solution. 
In another experiment performed with cresol C.P. (this being legs acidic) after two hours an aditional 1.2 c.0. $0.01 \mathrm{M} \mathrm{NaOH}$ was required by the $\mathrm{NaCl}$ solution. After eight hours 2.25 c.c. $0.01 \mathrm{M} \mathrm{NaOH}$ more was required.

This considerable amount of excess acid formed in the sodium chloride solution shaken with the cresol plus fatty acid mixture can hardly be due to anything else but hydrochloric acid formation by interaction of sodium chloride and fatty acid.

We have demonstrated by titration the presence of HCl in the solution; the detection of the presence of soap (Na oleate) is all that is now needed to prove that this chemical reaction occurs. The question is, how can this be done? We can see whether the cresol mixture which has produced the acid contains soap by titrating it as an alkali. The cresol mixture after having been shaken with sodium chloride is now shaken with pure water. It should yield alkall, at least, more alkali than that cresol mixture which previously had been shaken with water only, and hence yielded less acid. This theoretical conclusion has also been verifled as the following figures show.

After two hours 0.8 c.c. of $0.01 \mathrm{M}$ sodium hydroxide (less than for the mixture shaken with sodium chloride) was required, while after eight hours 8.0 c.c. of 0.01 I sodium hydroxide (less than for the mixture shaken with sodium ohloride) was required.

These experiments clearly show that sodium chloride can be split up into hydrochloric acid and a basic constituent. 
Application of the Phase Boundary Potential Theory to

Organic Bases Which Are Used as Central Conductors.

Thus far the phase boundary potential theory has been applied to non-aqueous organio fluids which contained a water insoluble acid or have had acid properties themselves.

E.8.: salicylic aldehyde plus salicylic acid cresol plus oleic acid

guaiacol plus oleic acta

If an organic base instead of an organic acid is used as a central conductor it should be expected to exhibit electromotive changes in the opposite direction. In fact, a certain base like ortho toluidine does exhibit an effect of concentration in the opposite direction. (Impurities moy alter this change.)

Series of measurements were made with $\mathrm{NaCl}$ solutions. The experimental arrangement is shown in Fig. 1 . The ortho toluidine is poured into the hook-shaped electrode wille NaCl solutions of varying concentrations are poured into the beakers and a measurement is made of the electromotive force of each solution. Connections to a measuring instrument (a sensitive electrostatic electrometer) are made by means of two calomel electrodes in the manner shown in the diagram. A variation of 0.079 rolt was found for a change of concentration from $1 / 10$ 
molecular to a $1 / 1250$ molecular $\mathrm{NaCl}$, the latter being on the positive side; hence the effect of concentration is opposite to that on salicylic eldehyde, with ali reutral salts such an inverse electromotive effect can be observed particularly well with KSCN. The latter substance shows a change of 0.107 volts for a variation of the concentration from $1 / 10$ molecular to $1 / 1250$ molecular.

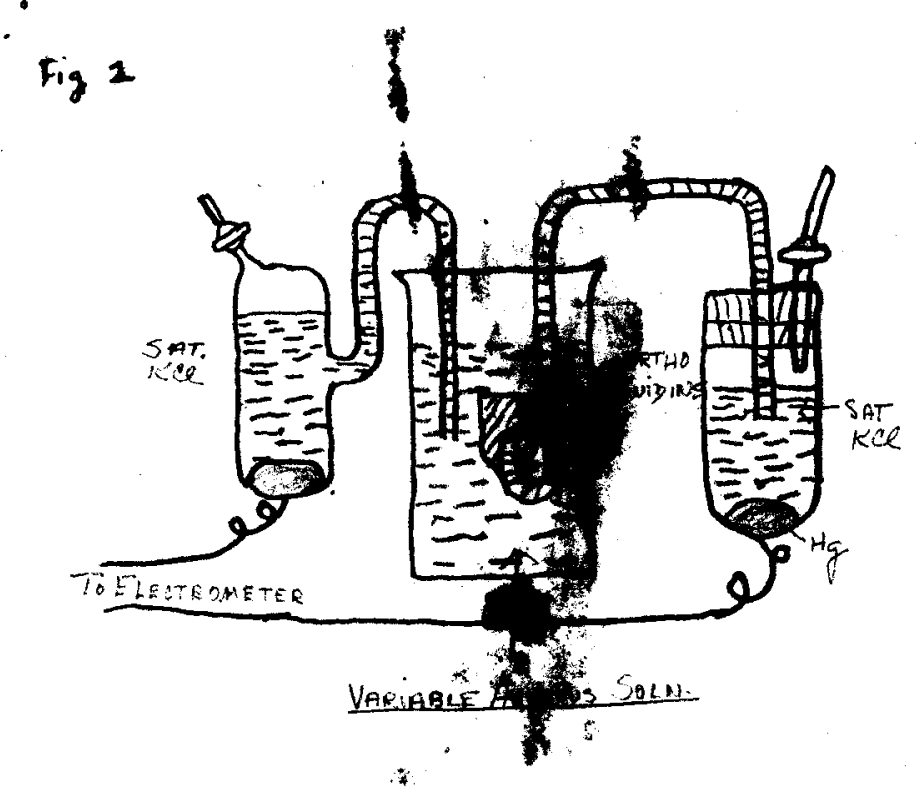


Shaking and Titration Experiments with Ortho Toluidine to Detect the Ifberation of a Base.

According to the theory a chemical reaction should occur between the ortho toluidine and the various salt solutions whereby a base should be liberated. Shaking experiments were performed using equal quantities of ortho toluidine with the 1 same quantities of various 0.1 at salt solution. These mixtures were shaken for several hours, then centrifuged for the separation of the layers and then filtered and titrated. Control experiments were used while salt errors were omitted by applying the same process which I have explained previously. Phenolphthalein was used as an indicator.

\section{Observations}

I. With $\mathrm{CaCl}_{2}$

$$
\begin{aligned}
& 15 \text { c.o. ortho toluidine }+15 \mathrm{c} . \mathrm{c}_{\text {. }} \mathrm{N} / 10 \mathrm{CaCl}_{2} \\
& \text { were shaken for several hours }
\end{aligned}
$$

On titration

$$
10 \text { c.c. of the filtrate }\left(\mathrm{CaCl}_{2}\right) \text { required } 0.320 \text { of }
$$
$0.989 \mathrm{~N} / 100 \mathrm{NaOH}$ to turn phenolphthalein pink.

II. $15 \mathrm{c.c}$. ortho toluidine + 15 c.c. of distilled water were also shaken for several hours for control purposes.

10 c.c. of the filtrate (distilled water) was titrated with 0.140 c.c. of $0.989 \mathrm{M} / 100 \mathrm{NaOH}$ 
From the experimental data one notices that the $\mathrm{CaCl}_{2}$ solution after shaking was slightly acidic and required the addition of 0.320 of $0.989 \mathrm{~W} / 100 \mathrm{HaOH}$ to make it basic.

I. With Iicl the same phenomenon was observed.

15 c.c. ortho toluidine +15 c.c. $\mathrm{M} / 10 \mathrm{LiCl}$ were shaken for several hours

10 c.c. of filtrate required 0.270 c.c. of $0.989 \mathrm{~W} / 100$ $\mathrm{NaOH}$ for titration

II. 15 c.c. ortho toluidine +15 c.c. of distilled water shaken for several hours

10 c.c. of filtrate (distilled water) required 0.135 c.c. of $0.989 \mathrm{~W} / 100 \mathrm{NaOH}$ for titration

When KI or KCNS were shaken with ortho toluidine, the liberation of a base was detected upon the addition of 3 drops of phenolphthalein to the filtrates.

\section{Experimental Evidence}

I. $\quad 15$ c.e. ortho toluidine +15 c.c. M/10 KCNS were shaken for several days. When to 10 c.c. of the filtered fluid 3 arops of phenolphthalein were added a deep permanent pink color was obtained, thus proving that a base was liberated during the shaking of ortho toluidine with KCNS. This agreed with the inverse electromotive effect of concentration which was most readily observed with KCNS and KI. 
II. As a control experiment,

15 c.c. of distilled water was shaken with o.toluidine. When 3 drops of phenolphthalein were added to the filtrate, the indicator did not turn pink and it required 0.40 c.c. of $\mathrm{M} / 100 \mathrm{NaOH}$ to bring the fluid to the same pink color obtained in I above.

When the same procedure was applied to a $\mathrm{K} / 10 \mathrm{KI}$ solution, the following results were obtained.

I. 15 c.c. ortho toluidine +15 c.c. of $\mathrm{M} / 10 \mathrm{kI}$ were shaken for two days

10 c.c. of filtrate +3 drops of phenolphthalein pink color - similar to that of KCNS.

II. 15 c.c. of ortho toluidine +15 c.c. of distilled $\mathrm{H}_{2} \mathrm{O}$ were also shaken for two days

10 c.c. of filtrate +3 drops of phenolphthalein required the addition of 0.32 c.c. $N / 100 \mathrm{NaOH}$ in order to equal the pink color of I above.

From the experiments with organic bases, one can accept the following conclusions:

1. An inverse electromotive force effect is obtained opposite to that of organic acids.

2. A chemical reaction occurs between the organic base and the salt solution at their phase boundaries, whereby $a$ base is liberated. 
It is not surprising that such a liberation of a base is not readily observed in some cases, since the electromotive force effect of concentration is not always readily observed due to the presence of impurities. Much difficulty may be encountered in producing this effect due to the presence of impurities. Variation in the types of impurities found in different samples of toluidine influences the results markedly. 
EXPERIMENTAI EVIDENCES AGAINST UICHAELIS' PORE THEORY. 
Experimental Bvidences Against Michaelis' Pore Theory.

The phase boundary potential theory caused some disagreement among biophysicists. I. Michaelis and his coworkers were its chief opponents. In 1925 Michaelis introduced the diffusion potential theory (4-12) as an explanation for the mode of action of membranes. This theory attributed the potential differences produced by membrenes to the difference in velooity of the single ions diffusing across the membrane. Furthermore, Michaelis claims that there is no abrupt change in the potential at the boundary of the membrane, but a gradual change of the potential from the one boundary towards the other, as in the case of a liquid junction potential when two electrolytic solutions are in direct contact with each other, and by diffusion or convection a gradual transition between the two solutions is interposed.

To explain this theory of diffusion potential, Michaelis used a dried collodion membrane. This membrane Michaelis said, acted as a molecular sieve, i.e., the retention of ions by an oppositely charged molecular wall. He observed that well dried collodion film showed an electrode-like electromotive action and that these forces came about not through a phase boundary potentiel but by means of electrically charged pores which act as an ionic filter. However, Michaelis was well aware of the possibility of explaining such an electromotive force as a re- 
sult of phase boundary potential, for this system - conc. $\mathrm{NaCl}\left|\begin{array}{c}\text { certain water immiscible fluids } \\ \text { like salioylic aldehyde }\end{array}\right|$ ail. $\mathrm{NaCl}+$ had a similar electromotive force. He even admitted that this explanation was not necessarily to be applied to the electrodelike action of plant cuticula. Nevertheless, Michaelis claimed that the theory of phase boundary potential could not be applied to the dried collodion film for the following reason, which will be stated in his own words ( 5 ).

"A completely dried collodion membrane is a perfect electric insulator and is highly electrified by gently rubbing it against the hair. Not being easily wetted by water, it retains its electric charge a very long time even in a humid atmosphere. This property of an electric insulator may be emphasized because it shows that the properties of permeability and electric conductivity are due to the pores and their contents and not to the chemical or physical nature of the solid nitrocellular substance. When such a membrane is thick enough and separates two electrolytic solutions, the conductivity is, at the beginning, almost zero. It increases, however, rapidly with the progress of imbibition by the membrane. Now it would be absurd to suggest that water or a potassium chloride solution could go into "solid solution" in the dried collodion within some minutes."

Thus Michaelis, in his experimental work was able to say that this dried collodion membrane acted as a molecular sieve, retaining ions of one kind due to the charge of the membrane wall, and that it would be ridiculous to suggest that water or a potassium chloride solution can go into solution in this membrane within some minutes. 
Michaelis' arguments are not convincing enough since experimental evidences show that not only a "going into solution" occurs but also chemical reactions can be very easily demonstrated. John H. Northrop, in his article on "The Permeability of Thin Dry Collodion Membranes" (13,14)states that gases do not pass through holes in theocollodion membrane, for the rate of diffusion would then be inversely proportional to the square root of their density and experiments show that a number of gases pass much more rapidly than hydrogen. Taken as a whole, results indicate that the substance first dissolves in and then diffuses through the membrane. Thus water, also must dissolve in the substance of collodion which would account for the increase of conductivity even if the filling of the pores played no part. This proof favors the assumption of the "going into solution" in the collodion rather than of a passage through the pores.

Collodion or ritrocellulose is a highly reactive substance and it is capable of entering into surface reactions with aqueous salt solutions like $\mathrm{KCl}$, and $\mathrm{NaCl}$ whereby $\mathrm{HCl}$ and a sodium compound of nitrocellulose are formed. Thus the presence of a chemical reaction at the surface of the dried collodion film con be very easily demonstrated. Furthermore, the theory of phase boundary potential is very applicable in this case. When $\mathrm{NaCl}$ is shaken with collodion, in a shaking machine, for several days, the $\mathrm{Na}^{+}$ion attaches itself to the collodion and 
a constant $\mathrm{Na}^{+}$ion concentration is present in the collodion. This produces an electromotive force similar to the one observed by Michaelis hecayse the $\mathrm{N}^{+}$fon concentration is thus kept contant at the surface of the dried collodion film and the following cell system was set up.

$$
\begin{array}{l|l|l}
\text { - aq. NaCl solu. } & \begin{array}{l}
\mathrm{Na} \text { collodion comp. } \\
\text { constant } \mathrm{Na} \text { conc. }
\end{array} & \text { approx. NaCl solu. } \\
\text { constute }
\end{array}
$$

Titration experiments were performed by $R$. Beutner showing the liberation and the detection of $\mathrm{HCl}$ and the following conclusions were accepted by him.

1. Collodion will give off traces of acid when shaken with salt solutions.

2. Collodion will even give off slight traces of acld when shaken with water. This is probably due to impurities contained in the water.

So far it has been shown that there is a "going into solution" in the collodion membrane and that there is a chemical reaction occuring on the surface of the collodion film between the collodion and the common ion of the aqueous solution. These evidences weaken I. Michaelis' pore theory of diffusion potential theory immensely.

There are, moreover, a few other arguments in opposition to Michaelis' pore theory.

1) Michaelis claims that if two KCl solutions of varying concentrations are separated by a dried collodion membrane, a dif- 
ference in potential will be produced due to the filling of the pores of the membrane from opposite sides. Suppose, howerer, we insert liquid collodion, ether and alcohol (see diagram below) between one of the $\mathrm{KCl}$ solutions and the collodion membrane, then the filling of the pores with KCI solutions from opposite sides should be obviated and no influence of the concentration upon the electromotive force of this system should appear according to the pore theory. But experimental evidences show that when the KCl concentrations were changed the electromotive force varied in the same manner as on an ordinary dried collodion film, hardly making any difference which solution was first epplied.

The following cell system was set up. \begin{tabular}{c|c}
$\mathrm{KCl}+$ lfquid collodion & $\begin{array}{c}\text { solld dried } \\
\text { collodion }\end{array}$
\end{tabular} $\mathrm{KCl}$ of varying conc.

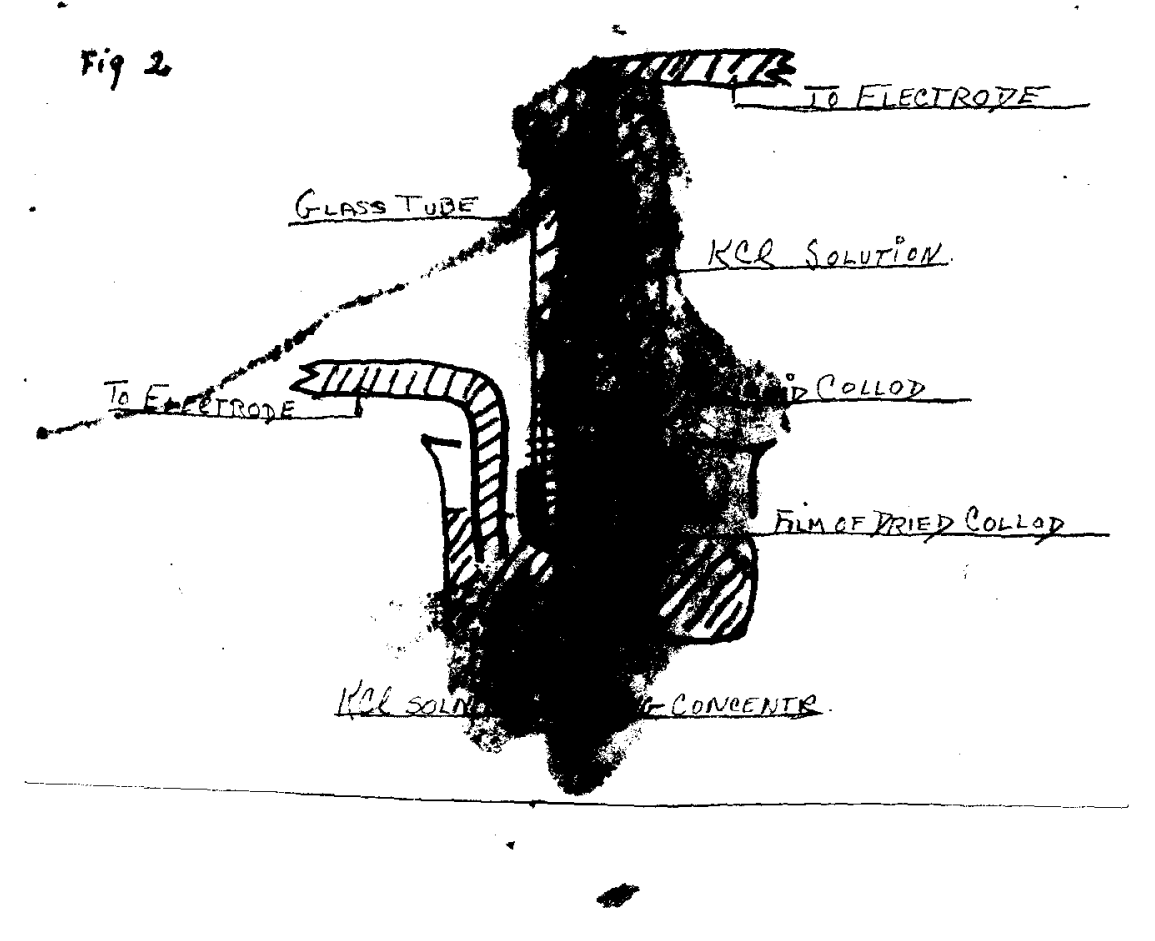




\section{Experimental Results}

Membrane plus a $2 \mathrm{~mm}$ column of collodion solution was used.

Membrane \#1

\begin{tabular}{|c|c|c|c|c|c|c|c|c|c|c|}
\hline Elec & System & Elec. & & & & & & & & \\
\hline Left & Membrane \#1 & rt. & down & up & down & up & down & up & down & Ave. \\
\hline+ & $\frac{M}{10} K C l / \frac{M}{10} K C l$ & - & 82 & 80 & 83 & 82 & 81 & 82 & 82 & 82 \\
\hline+ & $\frac{M}{10} K C 2 / \frac{M}{100} K C l$ & - & 112 & 110 & 113 & 114 & 112 & 113 & 112 & 112 \\
\hline+ & $\frac{M}{10} K C l / \frac{M}{1000} K C l$ & - & 155 & 153 & 153 & 157 & 156 & 157 & 154 & 155 \\
\hline+ & $\frac{M}{10} K C l /{ }_{\text {Hist. }}$ & - & 148 & 150 & 146 & 148 & 148 & 148 & 147 & 148 \\
\hline
\end{tabular}

Same method was applied except measurements were made, first, with very dilute solutions and then with highly concentrated ones.

Membrane \#2

\begin{tabular}{|c|c|c|c|c|c|c|c|c|c|c|}
\hline eft & Membrane \#2 & rt. & dowm & pג & down & up & dowm & $u p$ & down & \\
\hline+ & $\frac{M}{10} \mathrm{KCl}$ loôd KCl & 一 & 149 & 151 & 153 & 154 & 152 & 151 & 152 & \\
\hline+ & $\frac{M}{1 O} K C C^{\prime} / M O K C l$ & 一 & 106 & 110 & 110 & 109 & 107 & 108 & 110 & 10 \\
\hline+ & $M O K C l / M K C$ & - & 79 & 78 & 81 & 81 & 82 & 80 & 82 & \\
\hline+ & $\frac{M}{10} K C l /$ Dist. & 一 & 147 & 148 & 149 & 148 & 147 & 147 & 147 & 147 \\
\hline
\end{tabular}

From these results one con readily see that the liquid collodion used between the KCl solution and the collodion membrane does not stop changes in the electromotive force when the concentrations of $\mathrm{KCl}$ solutions are varied. According to Michaelis' 
pore theory, no variation in the electromotive force should occur in a cell system set up in this manner.

One may account for this discrepancy by the assumption that there are some pores left and that these are filled on the first contact with a given $\mathrm{KCl}$ solution which stays in the pores and comes into contact with the solutions subsequently applied. If this is the explanation, the observed electromotive force ought to depend on the concentration which was first applied. Our experinental results, as already seen above, show that this is by no means the case.

2) Another consideration against Michaelig' pore theory. Michaelis favors the diffusion potential theory against $R$. Beutner's phase boundary potential theory. If Michaelis' theory were correct, then the electric potential of a mixture of two electrolytes separated by a non-aqueous water immiscible substance should be a midale value of the value of the two components. Experimental evidences, however, show that this is not true.

An apparatus as shown in Fig. 3 was used.

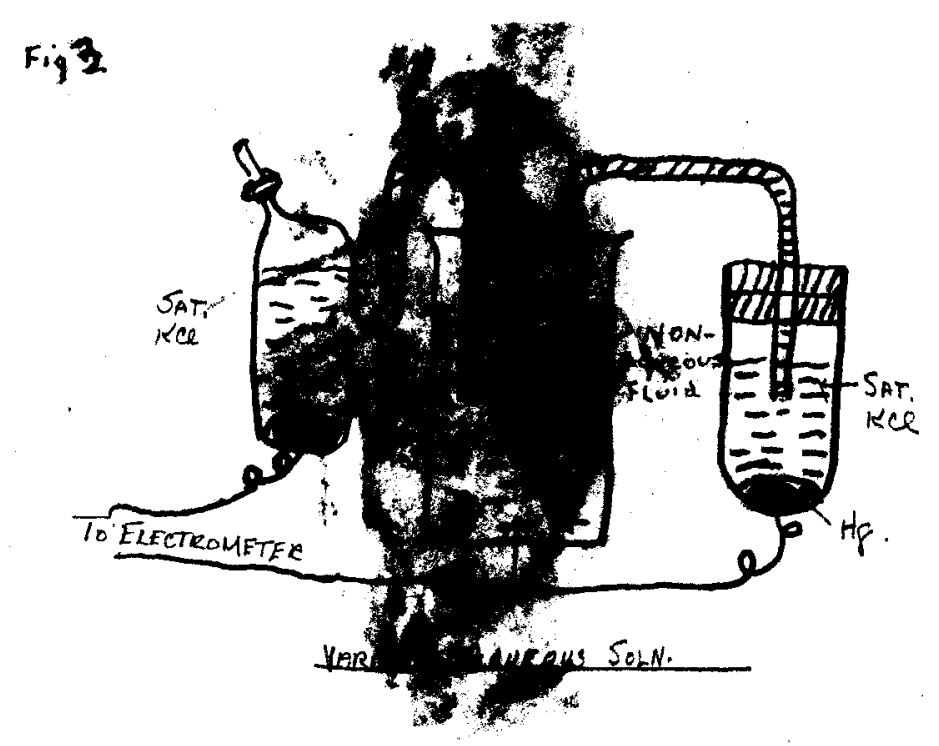


The hook-shaped electrode was filled with water immiscible olly liquids and immersed first in a $\mathrm{M} / 10 \mathrm{HCl}$ solution, then into a $\mathrm{KCl}$ solution and finally into a mixture of equal parts of $\mathrm{HCl}$ and $\mathrm{KCl}$ solutions. The electromotive foree of each substance was measured.

\section{Guaiacol}

$\mathrm{M} / 10 \mathrm{HCl}$

$\mathrm{M} / 20 \mathrm{HCl}+\mathrm{K} / 20 \mathrm{KCl}$

$\mathrm{M} / 10 \mathrm{KCl}$

0. Cresol

$\mathrm{M} / 10 \mathrm{HCl}$

$\mathrm{M} / 20 \mathrm{HCl}+\mathrm{M} / 20 \mathrm{KCl}$

$\mathrm{M} / 10 \mathrm{KCl}$

M. Cresol

M/10 $\mathrm{HCl}$

$\mathrm{M} / 20 \mathrm{HCl}+\mathrm{M} / 20 \mathrm{KCl}$

$\mathrm{M} / 10 \mathrm{KCl}$

Cellolain

M/10 HCI

$\mathrm{M} / 20+\mathrm{H} / 20 \mathrm{KCI}$

$\mathrm{M} / 10 \mathrm{KCl}$

$$
-0.005 \text { Volts }
$$$$
-0.003 \quad
$$$$
+0.020 \quad n
$$

$+0.064 \pi$

$+0.060 \quad "$

$+0.079 \quad$

$-0.017 \pi$

$-0.016 \pi$

$+0.004 \quad n$

$-0.070$

$-0.057 \quad$

$+0.006 \quad "$ 
From these experimental results, one readily observes that the electric potential of a mixture at a true phase - boundary is not a midale value of the values of the two components, but is always nearer to the value of the more penetrating salt.

It is interesting to note how potential differences between miscible solutions (usually known as diffusion potentials) produce different results. The electric potential of mixtures is found to be nearer the midale value of the values of the two components. Experimental evidences prove this to be true.

The same apparatus with the hook-shaped electróde is used in these experiments. "The only difference in this system is that the cup attached to the hook-shaped tube instead of being filled with a water immiscible oily substance is now filled fith concentrated HCl solution held in place by Gravel.

\section{Gravel electrode Experiment}
with
dilute $\mathrm{HCl}$ in the beaker
a mixture of $\mathrm{KCl} \& \mathrm{HCl}$
E.M.F.
$n$ -0.034 rolts
+0.050 n
+0.014

The electric potential of the mixture of $\mathrm{KCl}$ and $\mathrm{HCl}$ is a middle value of the two components.

* See page 26. 
If Michaelis' theory were correct then a mixture of $\mathrm{KCl}$ and HCl using collodion as a membrane, should produce an electric potential close to the midale value of the values of the two components $\mathrm{KCl}$ and $\mathrm{HCl}$. Observations show us, however, that this is not the case.

(1) with dilute HCl in contact with a collodion film $=-0.070 \mathrm{~V}$.

$$
\begin{array}{ccc}
\text { inside } & \text { collodion } & \text { outside } \\
\text { KCl } & \text { membrane } & \text { HCl } \\
(1 \mathrm{~mol}) & & .1 \mathrm{M}
\end{array}
$$

(2) with dilute $\mathrm{KCl}$ in contact with a collodion film $=+0.006 \mathrm{r}$.

$$
\begin{array}{ccc}
\text { inside } & \begin{array}{l}
\text { collodion } \\
\text { membrane }
\end{array} & \begin{array}{c}
\text { outside } \\
\text { KCI }
\end{array} \\
. I M & & . I M
\end{array}
$$

(3) with a mixture of $\mathrm{KCl}$ and $\mathrm{HCl}$

$$
=-0.057 \mathrm{\nabla} \text {. }
$$

$\begin{array}{clcc}\text { inside } & \text { collodion } & \text { outside mixture } \\ \text { KCl } & \text { membrane } & \text { HCl \& } & \text { KCl } \\ .1 M & & \text { M/20 } & \text { M/20 }\end{array}$




\section{SUMRARY.}

1. Organic acids, like salicylic eldehyde and cresol plus oleic acid, when interposed between aqueous solutions of different concentrations, will produce electromotive forces in a similar order of magnitude to those which appear in living tissues.

2. There is a chemical reaction occurring at the phase boundary of the cresol plus oleic acid and various salt solutions.

3. Organic bases produce inverse electromotive force effects opposite to that of organic acids.

4. A base is liberated when certain salt solutions like KI or KCNS are shaken with ortho toluidine. This is due to the high penetrability of the I' and CNS' ions in the ortho toluidine.

5. Experimental evidences against Michaelis' pore theory are:

a) Collodion is not an inert substance; there is a "going into solution" in the collodion membrane and a chemical reaction also occurs at the surface of the collodion film and the various salt solutions.

b) Iiquid collodion, inserted between the $\mathrm{KCl}$ solution and the collodion membrane, does not prevent any changes in the electromotive force when the concentrations of $\mathrm{KCl}$ solutions are varied. 
c) The electric potential of a mixture of two electrolytes separated by a non-aqueous water immiscible substance is not a midale value of the value of the two components. 


\section{BIBLIOGRAPHY}

(1) Beutner, R.: Physical Chemistry of Iiving Tissues and Iife Processes, Baltimore, Maryland.

(2) Beutner, R.: Die Entstehung Elektrischer Strome in Lebenden Geweben, pp. 1-14;61-71; 83-85.

(3) Loeb, J.: Proteins and the Theory of Colloidal Behavior, pp. 166-168.

(4) Michaelis, L.: Contributions to the Theory of Permeability of Membranes for Electrolytes. Journal of General Biology, Vol. 8, 31-66.

(5) Michaelis, I. and Perlzweig, W. A.: Studies on the Permeability of Membranes. I. Introduction and the Diffusion of Ions Across the Dried Collodion Membrane. Journal of General Biology, Vol. 10, 575-599.

(6) Michaelis, I., Ellsworth, R. McL. and Weech, A. A. : Studies on the Permeability of Membranes. II. Determination of Ionic Transfer Numbers in Membranes From Concentration Chains. Journal of Genersl Biology, Vol. $10,671-685$.

(7) Michaelis, L., Weech, A. A. and Yamatori, A.: Studies on the Permeability of Membranes. III. Electric Transfer Experiments With the Dried Collodion Membrane. Journal of General Biology, Vol. 10, 685-703. 
(8) Michaelis, I. and Weech, A. A.: Studies on the Permeability of Membranes. IV. Variations of Transfer Numbers With the Dried Collodion Membrane Produced by the Electric Current. Journal of General Biology, Vol. Il, 147-159.

(9) Weech, A. A. and Michaelis, I.: Studies on the Permeabil1ty of Membranes. V. The Diffusion of Non-electrolytes Through the Dried Collodion Membrane. Journal of General Biology, Vol. 12, 55-83.

(10) Weech, A. A. and Michaelis, I.: Studies on the Permeability of Membranes. VI. Mensuration of the Dried Collodion Membrane. Journal of General Biology, Vol. 12, 221-231.

(11) Green, A. A., Weech, A. A. and Michrelis, I.: Studies on the Permeability of Membranes. VII. Conductivity of Electrolytes Within the Membrane. Journal of General Biology, Vol. $12,473-487$.

(12) Weech, A. A. and Michaelis, I.: Studies on the Permeability of Membranes. VIII. The Behavior of the Dried Collodion Membrane Toward Bivalent Cations. Joumal of General Biology, Vol. 12, 487-495.

(13) Northrop, John H.: The Permeability of Thin Dry Collodion Membranes. Journal of General Biology, Vol. 11, 233-239. 
(14) Northrop, John H.: The Permeability of Dry Collodion Membranes. Jourmal of General Biology, Vol. I2, 435-463. 